University of Navarra

\title{
LIMITED PARTNERS' PERCEPTIONS OF THE CENTRAL EASTERN EUROPEAN VENTURE CAPITAL AND PRIVATE EQUITY MARKET
}

\author{
Alexander P. Groh \\ Heinrich Liechtenstein \\ Miguel A. Canela
}




\title{
LIMITED PARTNERS' PERCEPTIONS OF THE CENTRAL EASTERN EUROPEAN VENTURE CAPITAL AND PRIVATE EQUITY MARKET
}

\author{
Alexander P. Groh ${ }^{1}$ \\ Heinrich Liechtenstein ${ }^{2}$ \\ Miguel A. Canela ${ }^{3}$
}

\begin{abstract}
Growth expectations and institutional settings in Central Eastern Europe are assumed to be favorable for the establishment of a vibrant Venture Capital and Private Equity market. Despite this, there is a lack of risk capital. We examine the obstacles to institutional investments in the region through a questionnaire addressed to (potential) Limited Partners worldwide. The respondents provide information about their perceptions of the region. The protection of property rights is the dominant concern, followed by social criteria, such as the belief in the management quality of local people, and the insufficient size and liquidity of the Central Eastern European capital markets. However, Limited Partners regard the growth expectations as attractive, and those with exposure in Central Eastern Europe are satisfied with the historical risk and return ratio, have a good knowledge of the region, are attracted by other emerging regions, and appreciate the region's entrepreneurial opportunities and the local General Partners. Overall, the region is ranked very favorably compared to other emerging regions, and especially with respect to its economic and entrepreneurial activity.
\end{abstract}

\footnotetext{
${ }^{1}$ Professor GSCM - Montpellier Business School

${ }^{2}$ Professor, Finance, IESE

${ }^{3}$ Professor, University of Barcelona
}

JEL classifications: F3, G23, G24, P2

Keywords: Venture Capital, Private Equity, CEE, International Asset Allocation, Institutional Investors. 


\section{LIMITED PARTNERS' PERCEPTIONS OF THE CENTRAL EASTERN EUROPEAN VENTURE CAPITAL AND PRIVATE EQUITY MARKET}

\section{Introduction}

The Central Eastern European (CEE) ${ }^{1}$ countries are still in a transitional stage. EBRD (2005) emphasizes that improvements in governance, enterprise restructuring, and the financial sector have been the main features of the transition process in recent years. Kolodko (2000) and Wagner and Hlouskova (2005) argue that the CEE countries are going through a catch-up period that might last for several decades. This view is typically based on the observation that per-capita GDP in the CEE countries is still below the level of the European Union member states, while the level of education in CEE countries is high, and institutional structures have been converging for some time, as Süppel (2003) highlights. Schöfer and Leitinger (2002) point out that growth estimates above the European average, coupled with policies aimed at promoting innovative enterprises, should lead to a strong demand for risk capital in the CEE countries. Hence, CEE should be highly attractive to institutional investors in Venture Capital and Private Equity (VC/PE) Limited Partnerships.

However, the supply of risk capital is rather low compared to other European economies and relative to the expected growth opportunities in the CEE countries, even if institutional investors are increasingly looking internationally for new investment opportunities. The first funds were raised shortly after the fall of communism. According to EVCA (2004, 2005 and 2006), since then only a little more than $€ 9$ billion have been committed to VC/PE funds dedicated to CEE countries. This raises questions as to what obstacles face institutional investors prepared to invest in the VC/PE asset class in that region.

A large body of literature deals with issues concerning the evolution of vibrant local VC/PE markets, and with the parameters that determine institutional investors' decisions to allocate capital in economic regions. We contribute to the existing literature by directly incorporating these determinants into a questionnaire addressed to worldwide operating institutional investors as the dominant providers of risk capital. Consequently, we obtain a unique primary

\footnotetext{
1 We define CEE countries as those Central Eastern European countries that recently gained accession to the European Union; namely Bulgaria, the Czech Republic, Hungary, Poland, Romania, Slovakia, Slovenia (2004); and the Baltic States, which include Estonia, Latvia, and Lithuania (2007).
} 
data set to analyze the considerations and concerns of institutional investors when evaluating their VC/PE capital allocation opportunities in CEE. The questionnaire was sent electronically to 1,079 (potential) institutional investors in VC/PE Limited Partnerships in CEE (the Limited Partners - "LPs").

We can confirm that institutional investors regard the region as very favorably, on an equal ranking with India and slightly higher than China. Within CEE, LPs are most attracted by Poland, followed by the Czech Republic and Hungary. In the region, the institutional investors regard economic activity and the entrepreneurial opportunities as favorable but they are not satisfied with the local social environment and capital markets. However, the dominant concern when evaluating VC/PE allocation in CEE is the protection of property rights. Investors do not feel comfortable with the protection of their claims. The results are significant, and do not differ significantly among the sub-groups of institutional investors, such as, for example, Europeans and non-Europeans. Our results confirm previous findings on the importance of corporate governance rules, especially in emerging regions. It is not clear whether this perception is based on an accurate view of CEE property rights laws and the quality of their enforcement in the particular countries, or simply insufficient knowledge of a reality that could, in fact, be more favorable. In either case, policymakers should be aware that increasing investors' confidence could spur additional capital commitments and, hence, contribute to employment and growth.

Related literature so far discusses selections of several determinants for investments in CEE and provides evidence by regressions of VC/PE activity on proxies of these determinants. We are able, for the first time, to rank the appreciation of the particular parameters so far discussed in complementing research papers by directly addressing institutional investors as the main source of $\mathrm{VC} / \mathrm{PE}$ funding.

The paper is structured as follows: First, we review related literature. Then, we describe the study design and the resulting sample. Next, we perform comprehensive analyses of the data. Each analysis is immediately followed by an interpretation of the findings. Finally, we conclude.

\section{Literature Overview}

There is already a large body of papers regarding the evolution of foreign direct investments and the activity of (foreign and domestic) institutional investors in CEE and other emerging regions. Köke (1999) focuses on investment criteria of portfolio managers; Chan-Lau (2004) on the criteria of pension funds; Kaminsky et al. (2001) on the determinants of mutual funds; and Resmini (2000), Barrell and Holland (2000), Konings (2001), and Yudaeva et al. (2003) investigate determinants and consequences of foreign direct investments. They all find plenty of different parameters that positively or negatively affect institutional investment decisions, sometimes contradicting among the different papers.

Another large body of research deals with our asset class in question and explores the determinants of VC/PE activity in particular economies: Black and Gilson (1998), and Michelacci and Suarez (2004) highlight the important role of the stock market for the VC/PE asset class. Kaplan and Schoar (2005) confirm this. Jeng and Wells (2000) explore the determinants of VC/PE funding for 21 countries and expand the work of Black and Gilson (1998). They find that IPOs are the strongest driving force of VC/PE investing. Surprisingly, GDP growth and market capitalization are not significant. Gompers and Lerner (2000)

2 - IESE Business School-University of Navarra 
emphasize that risk capital flourishes in countries with deep and liquid stock markets. The availability of debt financing is another key factor for start-ups entering the market, as emphasized by Greene (1998), and hence a determinant for a VC/PE market. Additionally, the maturity of the $\mathrm{VC} / \mathrm{PE}$ market itself might attract investors. The maturity of a local $\mathrm{VC} / \mathrm{PE}$ market is also reflected by the number of players and supporting institutions, such as law firms, investment banks, M\&A boutiques, auditors and consultants. Sapienza et al. (1996) claim that the level of acceptance of the VC/PE market within a society, and the historical development of that market, both determine investor confidence. Balboa and Martí (2003) find that annual fundraising volume is dependent on the previous year's market liquidity. Chemla (2005) argues that the management of VC/PE funds is costly. Particular regions become attractive to investors only if the deal flow is large enough, and if transaction volumes and expected payoffs exceed a certain amount that allows management fees to be covered.

La Porta et al. (1997 and 1998) prove that the legal environment strongly determines the size and extent of a country's capital market and local firm's abilities to receive outside funding. Glaeser et al. (2001) and Djankov et al (2003 and 2005) suggest that parties in common-law countries have greater ease in enforcing their rights from commercial contracts. Cumming and Johan (2007) highlight that the perceived importance of regulatory harmonization increases institutional investors' allocations to the asset class. Desai et al. (2006) investigate the influence of institutional settings in 33 European countries, in particular the issues of fairness and the protection of property rights, on the entry of enterprises into the markets. The number of new enterprises proxies the attractiveness for VC/PE allocations. Cumming et al. (2006a) find that the quality of a country's legal system is much more directly connected to facilitating VC/PEbacked exits than the size of a country's stock market. Cumming et al. (2006b) expand on this and show that cross-country differences in legality, including legal origin and accounting standards, have a significant impact on the governance of investments in the VC/PE industry. Better laws facilitate deal-screening and deal-origination. They also facilitate investors' board representations and the use of desired types of securities. Lerner and Schoar (2004) analyze $\mathrm{VC} / \mathrm{PE}$ transaction structures in developing countries and find that the choice of securities is driven by the legal and economic circumstances of the nation and of the investing $\mathrm{VC} / \mathrm{PE}$ group. La Porta et al. (2002) find a lower cost of capital for companies in countries with better investor protection. Lerner and Schoar (2005) confirm these findings. Johnson et al. (1999) show that weak property rights limit the reinvestment of profits in start-up firms. Even so, Knack and Keefer (1995), Mauro (1995), and Svensson (1998) demonstrate that property rights significantly affect investments and economic growth.

Gompers and Lerner (1998) examine the forces that affected independent VC/PE fundraising in the United States. They conclude that factors such as regulatory changes affecting pension funds, overall economic growth, firm-specific performance and reputation all affect fundraising. They point out that there are more attractive opportunities for entrepreneurs if the economy is large and growing. Wilken (1979) argues that economic development facilitates entrepreneurship, as it provides a greater accumulation of capital for investments. Romain and van Pottelsberghe de la Potterie (2004) find that VC/PE activity is related to GDP growth.

Da Rin et al. (2005) argue that policymakers should consider a wide set of policies to improve emerging VC/PE markets, rather than simply channeling funds into the segment. Armour and Cumming (2006) confirm this rationale and show that government programs often hinder rather than help the development of VC/PE markets. 
Gompers and Lerner (1998) also stress that the capital gains tax rate influences VC/PE activity. Bruce (2000 and 2002), and Cullen and Gordon (2002) show that taxes affect the entry and exit of businesses. It can be concluded that this should be mirrored in VC/PE activity.

Rigid labor market policies might negatively affect the attractiveness of a VC/PE market. Institutional investors could hesitate investing in countries with exaggerated labor market protection and immobility. Lazear (1990), and Blanchard (1997) discuss how protection of workers can reduce employment and growth. Black and Gilson (1998) show that variations in labor market restrictions correlate with VC/PE activity.

Access to viable investments is probably another important factor for the attractiveness of a regional VC/PE market. In order to foster a growing risk capital industry, Megginson (2004) argues that the R\&D culture, especially in universities or national laboratories, plays an important role. Gompers and Lerner (1998) show that both industrial and academic RED expenditure is significantly correlated with VC/PE activity. Schertler (2003) emphasizes that the number of employees in the RED field and the number of patents, as an approximation of human capital endowment, have a positive and highly significant influence on VC/PE activity. Furthermore, Romain and van Pottelsberghe de la Potterie (2004) find that the level of entrepreneurship interacts with the REtD capital stock, technological opportunities, and the number of patents. Lee and Peterson (2000), and Baughn and Neupert (2003) argue that national cultures shape both individual orientation and environmental conditions, which lead to different levels of entrepreneurial activity in particular countries, and which should affect the level of acceptance of a risk capital culture. The acceptance of a risk capital culture in a society should also influence the funding activities of institutional investors.

Several papers focus on the evolvement of VC/PE in transition countries, and especially in CEE. Farag et al. (2004) focus on the VC/PE markets in Hungary, the Czech Republic, and Poland and compare them with the German market. With a sample of 68 GPs in the transition countries, they find several factors that hinder the CEE markets in catching up and reaching the chosen benchmark. They conclude that one clear, major obstacle is a lack of qualified people to manage the VC/PE backed enterprises, as the quality of management ranks highly as a reason for investment failure. This finding is also consistent with Bliss (1999), Karsai et al. (1998), and Chu and Hisrich (2001). Furthermore, debt financing remains limited, thus making it difficult to gain the desired returns by leveraging transactions. The authors suggest that legal and institutional improvements to protect lenders effectively can, therefore, lead to growth in the supply of risk capital. Johnson et al. (1999) emphasize the importance of property right protection in CEE, while they find access to banking finance does not present a problem. Klonowski (2005) defines 26 decision criteria for individual transactions in CEE economies, and identifies the most important ones through a survey of 200 GPs in various CEE countries.

All of the above-mentioned papers focus on the settings of several regional capital markets. Most of them run multivariate analyses on secondary data, some of them use surveys among General Partners. Our research approach differs: We directly assess the sources of VC/PE capital, the (potential) institutional investors on a worldwide scale, and collect, through a questionnaire, information about the parameters they evaluate when deciding on their VC/PE allocation in CEE. For the determination of the parameters we refer to the findings of the above-reviewed literature. As the second aspect, we directly ask the (potential) investors about their perceptions of the CEE region. Combining the findings of previous research and the unique primary data set we gathered, we are able to derive significant conclusions on the strengths and weaknesses of the region in attracting international capital. 


\section{Study Design}

\subsection{The Questionnaire and Addressees}

Due to space limitations we do not describe the questionnaire in detail (it is available from the authors on request) but, in short, it is divided in two parts. The first part contains some descriptive information on the respondent's institution in terms of its type, size, and allocation hurdle rates. Further, there are questions about the knowledge of the CEE region and the respondent's perception about CEE compared to other emerging regions. The second part comprehensively deals with the respondent's evaluation of the socio-economic criteria he or she considers for CEE asset allocation decisions and with his or her actual exposure there.

Some of the questions raised provide metric responses. However, the majority of the responses are ordinal, made via entries on a seven-point Likert scale. Other responses are categorical. The ordinal responses on the Likert scales range from "poor" to "excellent", or from "not at all attractive" to "very attractive," or from "not at all important" to "very important."

The survey was addressed via email to 1,079 Limited Partners worldwide. The geographic distribution of the addressees is as follows: 77\% United States and Canada, 17\% Europe, 5\% Asia, and 1\% others. The email addresses of the Limited Partners are collected from three commercial databases. It is not known what the entire population of LPs is in terms of numbers and funds under management, since a reliable or official list of institutional investors that qualify for VC/PE partnerships does not exist. Each of the three databases claims to cover the whole population of LPs, but, in matching them, we increase the number of players and, hence, gain a unique worldwide compendium of Limited Partners. Furthermore, we check several references and actively search for important and wellknown LPs manually in our repository. We deliberately attempt to cover as many LPs as possible. Nevertheless, matching the databases and the cross-checks might not secure a valid collection of LPs that, at least, represents the entire population. With regard to the geographical distribution of investors, for example, we have the following concern: Even though the United States, as an economic region and as the bestdeveloped financial market, probably embodies the biggest (in terms of fund volumes), most sophisticated, and with the largest number of LPs, other regions, notably Asia, might be underrepresented. However, in terms of funds under management, our data collection reliably represents the population. In our depository, none of the larger LPs should be missing, whether in the United States, Europe or Asia. The size of the LPs is important for our study, because, first, as described by Chemla (2005), only the larger ones will be able and willing to diversify into the emerging CEE market, and probably only from them would we receive a response. Second, the larger institutions are more important in terms of their market weight. Additionally, we expect the European LPs to be more interested in the CEE region (for reasons of proximity) and, correspondingly, we expect a higher response rate from them. Hence, we believe that an over-representation of the number of U.S. LPs in our depository of addresses will not harm our conclusions unless they respond in a different manner. However, we will address this issue and investigate our sample regarding differences in the allocation processes and different perceptions caused by geographic origins of the investors. We do not expect to receive many responses from Asian LPs, due to the existence of other emerging regions that would attract them more, for reasons of proximity. 


\subsection{Sample Size, Geographical Structure and Potential Bias}

Of the 1,079 Limited Partners addressed we received 75 valid and valuable responses. This response rate of 7\% is quite satisfying when compared to other studies that collect primary data about investors' behavior by means of a questionnaire. For instance, Lerner and Schoar (2005) collect data from 28 Private Equity funds, and Köke (1999) considers a sample of only 21 responses.

The responding LPs are segmented into the following groups: Corporate investors, government agencies, banks, pension funds, insurance companies, funds of funds, endowments, and others. A geographic distinction is made according to the origin of the investor: United States and Canada, Western Europe, CEE, and rest of the world. The segments are presented in Table 1.

\section{Table 1}

Segmented Respondents (Type and Origin of Investors)

\begin{tabular}{|l|c|l|c|}
\hline Type of Investor & Occurrence & Origin of Investor & Occurrence \\
\hline Corporate Investors & 4 & USA and Canada & 34 \\
\hline Government Agency & 1 & Western Europe & 37 \\
\hline Banks & 3 & CEE & 1 \\
\cline { 1 - 2 } Pension Funds & 8 & Rest of the World & 3 \\
\cline { 1 - 2 } Insurance Companies & 1 & & \\
\cline { 1 - 2 } Funds of Funds & 29 & & \\
\cline { 1 - 2 } Endowments & 2 & & \\
\cline { 1 - 2 } Others & 26 & & \\
\cline { 1 - 2 } Not Available & 1 &
\end{tabular}

Unfortunately, the response rate from LPs that qualify themselves as 'others' is relatively large, and therefore, only the 'funds of funds' group can be distinguished as homogeneous. Furthermore, as expected, we received more answers from European LPs $(49.3 \%$ of all the answers), as compared to their occurrence in our depository of $17 \%$. This might bias the results of our study. At any rate the geographical distribution might not be the only cause of a selection bias. As discussed below, types of investors, fund sizes, or other criteria might also not be sufficiently representative. Unfortunately, since no comparable comprehensive repository of investor data exists that provides the necessary information to correct for a potential bias, as mentioned above, we are unable to address this issue. However, we assess the responses of subgroups of investors, e.g. Europeans and non-Europeans separately in a subsequent section of this paper, and find that there are no meaningful differences in their international capital allocation approaches. This leads us to conclude that, even if our sample does not perfectly represent the worldwide population of (potential) Limited Partners, our findings are not biased.

\subsection{Funds Under Management and VC/PE Commitments}

Fifty-nine respondents provided information regarding the size of the managed funds, and from 68 we received their percentage allocation in the VC/PE asset class. Table 2 presents the distribution of the sample, segmented by size and by the worldwide percentage allocation in the $\mathrm{VC} / \mathrm{PE}$ asset class. 


\section{Table 2}

Segmented Respondents (Fund Size) and VC/PE Allocation

\begin{tabular}{|l|c|c|c|}
\hline Fund Size & Occurrence & VC/PE Allocation & Occurrence \\
\hline$<€ 100 m$ & 9 & $<30 \%$ & 29 \\
\hline$€ 100-999 m$ & 18 & $30 \%-89 \%$ & 8 \\
\hline$€ 1,000-9,999 m$ & 23 & $90 \%-100 \%$ & 31 \\
\hline$>€ 9,999 m$ & 9 & \multicolumn{2}{|c}{} \\
\cline { 1 - 3 } & \multicolumn{2}{|l}{}
\end{tabular}

The fund sizes are relatively heterogeneous, while the worldwide commitments to the VC/PE asset class are not. A large number of the funds allocate $90 \%$ or more of their funds under management into the asset class. This leads us to investigate the relationship between the size of the fund and the percentage of VC/PE allocation. We assume that the percentage of a fund's allocation in the VC/PE capital market segment decreases with the size of the fund. The reason for this is that the smaller funds might be specialized VC/PE vehicles that receive their capital from already-diversified investors, and do not need to diversify among different asset classes. Therefore, we perform a Kruskal-Wallis test with the hypotheses H0: $\mu_{\mathrm{i}}=\mu_{\mathrm{k}}$, and H1: $\mu_{\mathrm{i}} \neq \mu_{\mathrm{k}}$ to test whether the percentage allocation of the funds differs with fund size. The results are reported in Table 3 (note that 58 respondents provided information on both determinants).

\section{Table 3}

Kruskal Wallis Test on the Commitment to the VC/PE Asset Class, Grouped by Size

\begin{tabular}{|l|r|c|c|l|c|}
\hline $\begin{array}{c}\text { Funds under } \\
\text { Management }\end{array}$ & N & Mean Rank & $\begin{array}{c}\text { Mean \% commitment } \\
\text { to VC/PE }\end{array}$ & $\begin{array}{c}\text { \% } \\
\text { committed } \\
\text { to VC/PE }\end{array}$ \\
\hline$<€ 100 m$ & 9 & 24.06 & 41.844 & Chi-Square & 10.264 \\
$€ 100-999 m$ & 18 & 34.00 & 67.183 & df & 3 \\
$€ 1,000-9,999 m$ & 22 & 33.64 & 61.273 & Asymp. Sig. & .016 \\
$>€ 9,999 m$ & 9 & 15.83 & 22.667 & & \\
Total & 58 & & 54.102 & & \\
\hline
\end{tabular}

We find a significant difference in the mean commitments of the funds grouped by fund size. Hence, HO has to be rejected, but not in the expected way. The result is rather surprising and leads to the conclusion that the smallest and largest funds in our sample (with 41.8\% respectively with $22.7 \%$ average $\mathrm{VC} / \mathrm{PE}$ allocation in each group) have a smaller percentage allocation than the medium-sized funds (between $€ 100$ million and $€ 9.9$ billion, with average allocations of 67.2\%, and 61.3\% respectively). The medium-sized funds are the entities that are more specialized in VC/PE.

Regarding CEE exposure, we received responses from 59 LPs; 25 of which have no exposure in CEE; 23 funds have some exposure, less than $€ 50$ million; 4 have exposure ranging from $€ 50$ million to $€ 100$ million; while the remaining LPs have greater exposure. The minimum commitment to a single fund, required to satisfy cost/benefit ratios and internal hurdle rates of the LPs, is presented in Figure 1. 


\section{Figure 1}

Minimum Commitments to a Single Fund (55 Responses)

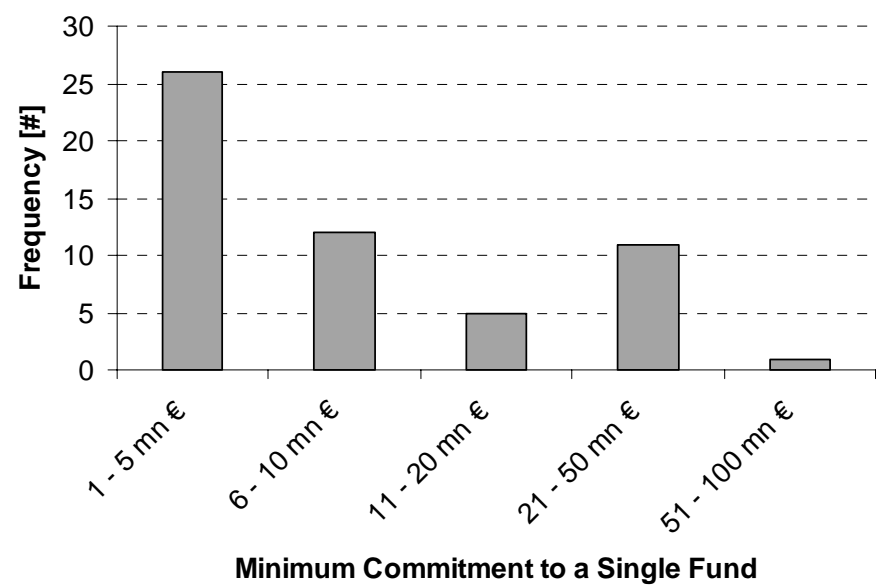

The information is provided by 55 respondents with a mean minimum exposure of $€ 13.5$ million, a median of $€ 10$ million and a standard deviation of $€ 16.1$ million. The particularly large minimal exposures are named by large funds-of-funds investors that probably strive for diversification on subsequent levels. More than two-thirds of the respondents name the minimum exposure in a single fund as being less than $€ 11$ million. Those investors better qualify for limited VC/PE partnerships in the CEE region, which are, with respect to the size of the market and typical transactions, smaller than those in Western Europe or North America.

Fifty-five LPs name their maximum commitment to a single fund in terms of the fund's stake, leading to an average of $18.6 \%$ and a median of $15 \%$ with a standard deviation of $17.2 \%$ points. Almost half of the respondents usually take minority stakes of the funds below 10\%, while the others are prepared to take stakes above 10\%. Two of the respondents would even subscribe for majorities. The clusters of the nominations are presented in Figure 2.

\section{Figure 2}

Maximum Commitment to a Single Fund in Terms of the Fund's Stake (62 Responses)

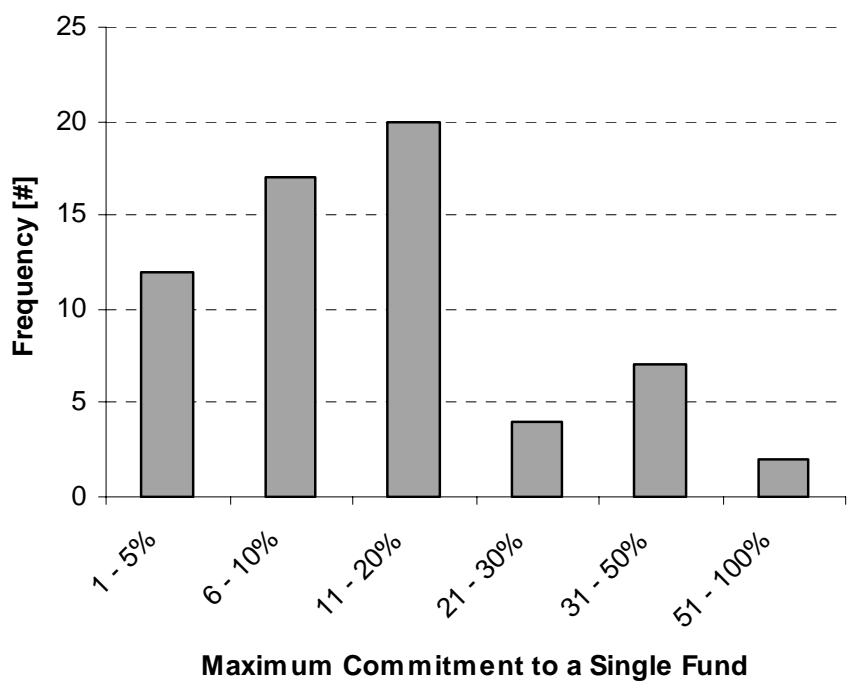

8 - IESE Business School-University of Navarra 
With regard to knowledge of the CEE region, the responses give an expected picture of our questionnaire participants. On the seven-point Likert scale, from "poor knowledge 1" to "excellent knowledge 7," the only participant from within the CEE region estimates his/her own knowledge of CEE as 6. We receive an average of 4.65 for the other European respondents, an average of 4.21 for the North Americans, and 3 for the rest of the world. In a subsequent question the participants are asked about the attractiveness of CEE for VC/PE allocations on the seven-point Likert scale. We find a significant $(p=0.006)$ Spearman's correlation coefficient of 0.33 , indicating that well-informed investors regard the region as attractive.

Summarizing the descriptive statistics, it can be reported that we receive a diverse sample of (potential) investors in the $\mathrm{VC} / \mathrm{PE}$ asset class in terms of size, type, relevant geographical origins, exposure in VC/PE, and thereof exposure in the CEE region. The data is comprehensively analyzed in the subsequent sections of this paper.

\section{Analyses}

The analyses are performed with several different statistical tests, bivariate and multivariate logit regressions. Since the number of responses differs among sub-groups of questions, multivariate analyses do not lead to significant results in some of the cases. This is mainly due to reduced data within the multivariate regressions caused by incomplete sets of answers from the survey participants. In those cases, we determine significant parameters in bivariate analyses. Within our statistical tests we follow the approach of not having prior expectations regarding the location of central parameters and hence, define non-directional alternative hypotheses.

\subsection{Preferences for Emerging Regions and Particular CEE Economies}

CEE is in competition with other emerging regions for attracting funding from investors. Hence, we are interested in investor preferences concerning different growth regions in the world, differentiating between Africa, CEE, China, CIS (Commonwealth of Independent States - the former Soviet Union), India, Latin America, and Southeast Asia. The respondents specify their perceptions on a range from "not at all attractive 1" to "very attractive 7" on the seven-point Likert scale. The mean nominations, the $\pm \sigma$ percentile, and the number of responses concerning the attractiveness of the different emerging regions are presented in Figure 3.

\section{Figure 3}

Attractiveness of Different Emerging Regions (Fluctuating Numbers of Responses)

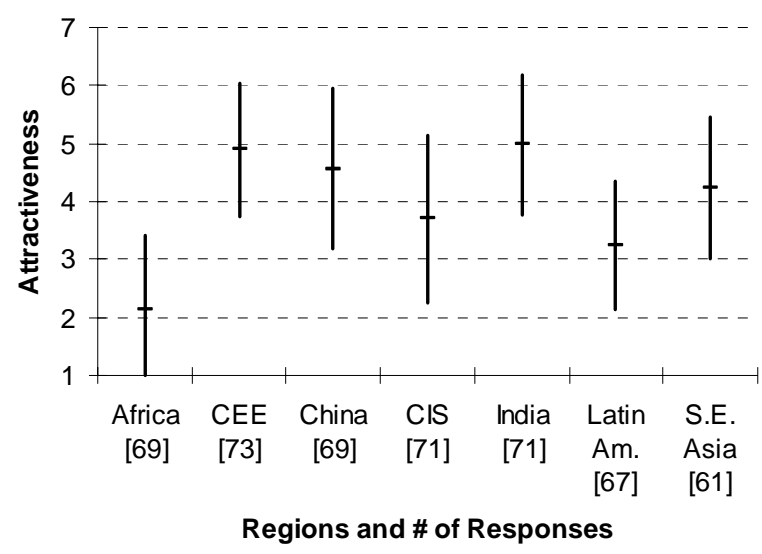


To obtain a clearer picture about the institutional VC/PE investors' ranking of the attractiveness of the emerging economies, we perform pair-wise Wilcoxon Signed Rank Tests. The Ho hypothesis in each case is: $\mu_{\mathrm{i}}=\mu_{\mathrm{k}}$, while the alternative H1 hypothesis is $\mu_{\mathrm{i}} \neq \mu_{\mathrm{k}}$. The test results are presented in Appendix 1. Unfortunately, the results still fail to provide a final ranking of the individual regions on a 0.05 significance level. Some ranks are tied. Table 4 presents the ranking according to the tests.

\section{Table 4}

Ranks of Attractiveness of Different Emerging Regions

\begin{tabular}{|l|c|}
\hline Region & Rank(s) \\
\hline India & 1 or 2 \\
\hline CEE & 1 or 2 or 3 \\
\hline China & 2 or 3 or 4 \\
\hline Southeast Asia & 3 or 4 \\
\hline CIS & 5 \\
\hline Latin America & 6 \\
\hline Africa & 7 \\
\hline
\end{tabular}

Referring to Table 4, we can define three tier groups: The first tier group consists of India (that can rank either 1 or 2), the CEE countries (1,2 or 3), and China, while China might also belong to the second tier group (either 2, 3 or 4, but always behind India), together with Southeast Asia (either 3 or 4, but always after CEE). CIS, Latin America, and Africa belong to the third tier group in the mentioned order of attractiveness. Similarly, we question the attractiveness of the individual CEE countries and present in Figure 4 the mean scores and the $\pm \sigma$-percentiles.

\section{Figure 4}

Attractiveness of the Individual CEE Countries (Fluctuating Numbers of Responses)

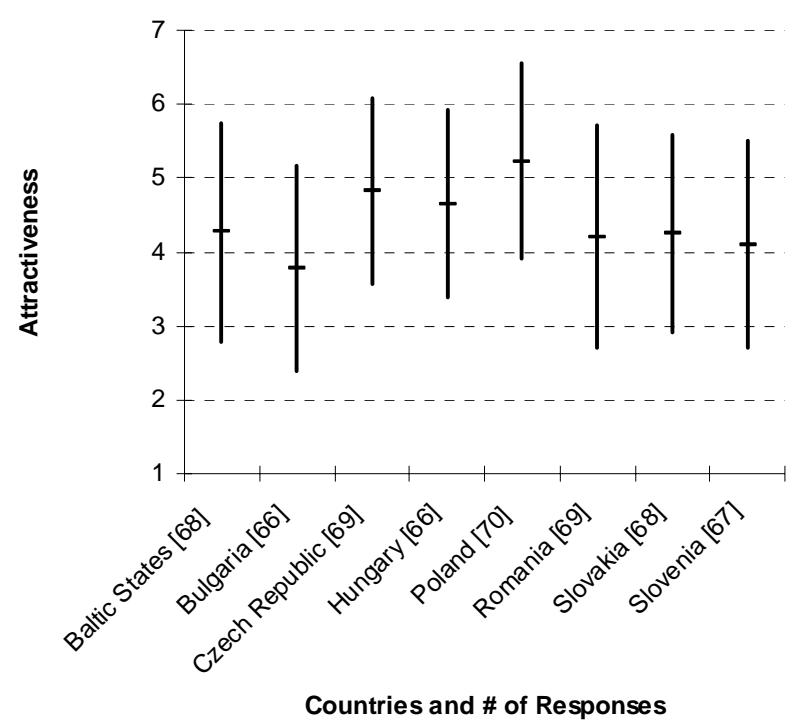


Again, a clear ranking is not possible on the basis of the mean scores, and we perform pairwise Wilcoxon Signed Rank Tests to test in each case if Ho: $\mu_{i}=\mu_{k}$, else H1: $\mu_{i} \neq \mu_{k}$. The test results are presented in Appendix 2. Unfortunately, as before, the tests do not reveal a final ranking of all the CEE countries' attractiveness for VC/PE investors on a 0.05 significance level. However, Poland ranks clearly before all the other CEE states. Subsequent ranks are tied but we can build three tier groups. The top tier group is Poland and the Czech Republic. The second tier is Hungary, the Baltic States, Romania, and Slovakia. The last tier consists of Slovenia and Bulgaria. Thereby, Hungary could also belong to the first tier, and Slovenia to the second tier group. The possible individual ranks are presented in Table 5.

\section{Table 5}

Ranks of Attractiveness for Institutional Investors of Different CEE Countries

\begin{tabular}{|l|c|}
\hline Country & Possible Rank(s) \\
\hline Poland & 1 \\
\hline Czech Republic & 2 or 3 \\
\hline Hungary & or 3 or 4 or 5 \\
\hline Baltic States & or 4 or 5 or 6 or 7 \\
\hline Romania & 3 or 4 or 5 or 6 or 7 \\
\hline Slovakia & 4 or 5 or 6 or 7 \\
\hline Slovenia & 4 or 5 or 6 or 7 or 8 \\
\hline Bulgaria & 7 or 8 \\
\hline
\end{tabular}

\subsection{Characteristics of Different Allocation Criteria in CEE}

To investigate investors' concerns about the CEE region we determine their ratings of the criteria discussed in our literature review. Therefore, we briefly describe the individual criteria and ask them to evaluate the region on the seven-point Likert scale from "not at all attractive 1 " to "very attractive 7," based on the following determinants: Capital market, social environment, investor protection, taxation, economic, and entrepreneurial conditions. The results are presented in Figure 5.

\section{Figure 5}

Key Determinants in CEE Region (Fluctuating Numbers of Responses)

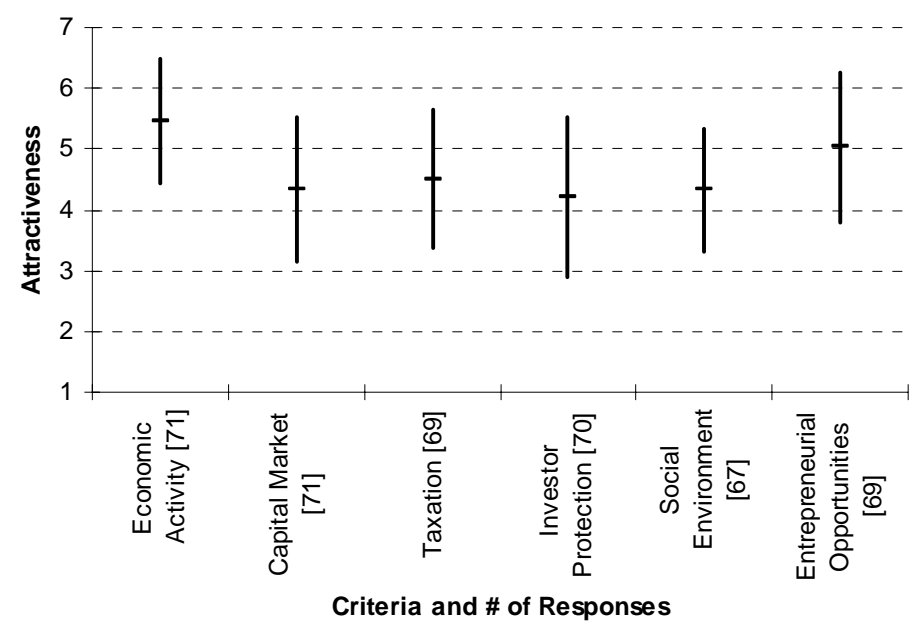


Figure 5 shows the means of the nominations and the $\pm \sigma$-percentiles regarding investors' satisfaction with the six key driving factors. Again, as no clear ranking across the key driving factors is possible, we perform Wilkoxon Signed Rank tests with the hypotheses H0: $\mu_{\mathrm{i}}=\mu_{\mathrm{k}}$, and H1: $\mu_{\mathrm{i}} \neq \mu_{\mathrm{k}}$. The tests are documented in Appendix 3 and the results presented in Table 6.

\section{Table 6}

The Attractiveness of CEE Countries with Respect to Six Country Allocation Key Driving Factors

\begin{tabular}{|l|c|}
\hline Criteria & Rank(s) \\
\hline Economic Activity & 1 \\
\hline Entrepreneurial Opportunities & 2 \\
\hline Taxation & 3 or 4 or 5 \\
\hline Capital Market & 3 or 4 or 5 or 6 \\
\hline Social Environment & 4 or 5 or 6 \\
\hline Investor Protection & 4 or 5 or 6 \\
\hline
\end{tabular}

It becomes clear that, while economic and entrepreneurial conditions are regarded as quite favorable, a very important investment obstacle, as described by La Porta et al. (1997, 1998, and 2002), Glaeser et al. (2001), Djankov et al. (2003 and 2005), and Lerner and Schoar (2005), namely, the protection of property rights, is ranked poorly. Johnson et al. (1999) also emphasize this finding for the CEE region. Other important criteria discussed in the literature overview, such as the presence of qualified GPs and expected entrepreneurial management quality and skills, are largely determined by the social and capital market environment in these countries, and also receive the lowest rankings. Institutional investors miss a satisfying level of investor protection, entrepreneurial management skills, and capital market activity. Thereby, it is not relevant whether these perceptions are based on correct specifications of the proposed key driving factors, or on insufficient knowledge of a reality that could, in fact, be more favorable. Either way, increasing investor confidence regarding those issues could spur additional commitments.

\subsection{Grouping Investors}

Our heterogeneous sample of 75 LPs allows partitioning in several homogeneous sub-samples. The following categories can be assigned to the respondents: They are either European or not; they are either funds of funds or not; or they either can or cannot be grouped into entities that are focused on VC/PE investments, and hence specialized (with high percentage VC/PE exposure). All of the criteria split the sample roughly by half. The research question for the subsamples is always whether there are any differences regarding their capital allocation processes or their perceptions. We obtain the required results by running Mann Whitney U tests. First, we distinguish European and non-European LPs.

It could be argued that European investors have a better knowledge of CEE than non-Europeans due to the geographic proximity. Additionally, Europeans could follow other criteria for their international asset allocation process. To test those and similar hypotheses we perform Mann Whitney U tests, using Ho: $\mu_{\mathrm{i}}=\mu_{\mathrm{k}}$, and $\mathrm{H} 1: \mu_{\mathrm{i}} \neq \mu_{\mathrm{k}}$. The test statistics with significant results are presented in Table 7. 


\section{Table 7}

Test Statistics with Significant Results

\begin{tabular}{|c|l|r|r|r|r|r|r|}
\hline \multirow{2}{*}{ European } & & $\begin{array}{c}\text { Max \% in } \\
\text { Single } \\
\text { Fund }\end{array}$ & China & \multicolumn{1}{c|}{ CIS } & India & $\begin{array}{c}\text { Taxation in } \\
\text { CEE }\end{array}$ & $\begin{array}{c}\text { Baltic } \\
\text { States }\end{array}$ \\
\hline 0 & $\mathrm{~N}$ & 30 & 31 & 33 & 33 & 33 & 32 \\
& Mean & 22.733 & 4.19 & 4.12 & 4.67 & 4.88 & 4.72 \\
& Std. Deviation & 17.7840 & 1.327 & 1.576 & 1.190 & 1.139 & 1.397 \\
\hline \multirow{2}{*}{1} & N & 33 & 37 & 37 & 37 & 35 & 35 \\
& Mean & 14.364 & 4.84 & 3.27 & 5.30 & 4.17 & 3.91 \\
& Std. Deviation & 15.9390 & 1.385 & 1.146 & 1.175 & 1.043 & 1.422 \\
\hline \multirow{3}{*}{} & Mann-Whitney U & 296.500 & 421.500 & 421.500 & 444.000 & 368.500 & 388.00 \\
& Z & -2.770 & -1.920 & -2.274 & -2.019 & -2.679 & -2.203 \\
& Asymp. Sig. (2-tailed) & .006 & .055 &. $\mathbf{0 2 3}$ &. $\mathbf{0 4 3}$ &. $\mathbf{0 0 7}$ & $\mathbf{. 0 2 8}$ \\
\hline
\end{tabular}

Table 7 presents the test statistics for the analyses, where partitioning the sample into European $(=1)$ and non-European $(=0)$ LPs gives significant results (also having tested for all the other possible parameters). The results reveal that non-European investors are prepared to maintain a higher maximum exposure in a fund. They regard the CIS region as more attractive than the Europeans, and India less attractive. They also regard China as less attractive (at a 0.055 significance level). There is some kind of "inverse relationship" between the proximity of a region and perceptions about it. The European and non-European investors likewise regard more distant regions as more attractive. They evaluate taxation in CEE as worse than the nonEuropeans. This could be due to a better knowledge and understanding of the CEE tax regimes, or due to regulations that only non-Europeans can benefit from. Furthermore, they regard the Baltic States as less attractive than the non-Europeans. However, we do not find significant differences between European and non-European LPs regarding their evaluation of their own knowledge of CEE, or any other determinant than those mentioned. This allows us to conclude that institutional investors operating on an international level do not differ greatly across different regions of origin in their approaches to international capital allocation.

The following analyses deal with differences between a) those funds dedicated to VC/PE only, and $b$ ) the rest. We distinguish the funds dedicated to the VC/PE asset class from others on the basis of the percentage of fund allocation to VC/PE being higher than 90\%. It could be argued that the focused funds are more experienced and more professional in their due diligence and allocation processes. Additionally, they might have better knowledge of the VC/PE markets and local conditions in different regions of the world. To test these and other hypotheses, we perform Mann Whitney U tests again, using HO: $\mu_{\mathrm{i}}=\mu_{\mathrm{k}}$, and $\mathrm{H} 1: \mu_{\mathrm{i}} \neq \mu_{\mathrm{k}}$. Table 8 presents the test statistics with significant results. 


\section{Table 8}

Test Statistics with Significant Results

\begin{tabular}{|c|l|r|r|r|r|r|}
\hline $\begin{array}{c}\text { VC/PE } \\
\text { Focused }\end{array}$ & & $\begin{array}{c}\text { Binary } \\
\text { Commitment } \\
\text { to CEE }\end{array}$ & $\begin{array}{c}\text { Max \% in } \\
\text { Single } \\
\text { Fund }\end{array}$ & $\begin{array}{c}\text { Latin America } \\
\text { Attractiveness }\end{array}$ & $\begin{array}{c}\text { Capital market } \\
\text { in CEE }\end{array}$ & $\begin{array}{c}\text { Taxation } \\
\text { in CEE }\end{array}$ \\
\hline 0 & $\mathrm{~N}$ & 36 & 36 & 35 & 37 & 35 \\
& Mean & .42 & 16.556 & 3.60 & 4.70 & 4.83 \\
& Std. Deviation & .500 & 17.3575 & 1.063 & 1.244 & 1.071 \\
\hline 1 & $\mathrm{~N}$ & 29 & 23 & 28 & 29 & 29 \\
& Mean & .66 & 21.565 & 2.82 & 4.07 & 4.17 \\
& Std. Deviation & .484 & 17.7478 & 1.020 & .998 & 1.167 \\
\hline & Mann-Whitney U & 397.500 & 303.500 & 300.000 & 387.500 & 376.500 \\
& Z & -1.899 & -1.743 & -2.755 & -1.992 & -1.849 \\
& Asymp. Sig. (2- & .058 & .081 & .006 & .046 & .065 \\
\hline
\end{tabular}

Table 8 presents the test statistics for the analyses, where splitting the sample into VC/PE specialized $(=1)$ and non-specialized $(=0)$ LPs leads to significant results (also having tested all the other parameters). The analyses reveal that funds dedicated to the VC/PE asset class more often have a commitment in the CEE region than other funds (this and some other results discussed further below, are based on expanded significance levels, up to 0.081). The finding can be interpreted twofold: On the one hand, specialized VC/PE investors might more comprehensively perform regional due diligence, and hence might be aware of several favorable conditions in CEE. On the other hand, the greater commitment in CEE could also be due to geographic diversification requirements for the specialized VC/PE funds. Both arguments seem plausible, but because the focused funds do not evaluate CEE (statistically significant) as more attractive than their non-focused peers, the latter argument seems to be the more likely.

However, the specialized funds are willing to subscribe larger maximum stakes in single funds and they regard Latin America as less attractive than the general funds do. Furthermore, the focused investors evaluate the capital market and the tax regime in CEE as less attractive than do the non-specialized investors. A possible explanation for this finding might be, as above, a deeper regional due diligence by the specialized investors, especially in the tax regimes, which might not be so attractive in all facets. In summary, it can be argued that investors closer to the individual target investments have slightly different opinions with regard to several allocation criteria and country perceptions.

The final distinction is made by separating funds-of-funds from other categories of investors. Funds-of-funds will, as indicated by the name, diversify among different funds. They delegate the management activities to lower levels and, therefore, have to rely more on the subsequent chain of agents than other investors who can allocate their capital more directly. As a result, they should differ in respect to their allocation profiles, and they might have different asset allocation criteria and regional perceptions. To test these hypotheses we perform Mann Whitney U tests once again, using Ho: $\mu_{\mathrm{i}}=\mu_{\mathrm{k}}$, and $\mathrm{H} 1: \mu_{\mathrm{i}} \neq \mu_{\mathrm{k}}$. The test statistics with significant results are presented in Table 9 (again, we also tested all the other parameters). 


\section{Table 9}

Test Statistics with Significant Results

\begin{tabular}{|c|l|c|c|c|}
\hline $\begin{array}{c}\text { Fund of } \\
\text { Fund }\end{array}$ & \% Committed to & $\begin{array}{c}\text { Minimum } \\
\text { VC/PE }\end{array}$ & $\begin{array}{c}\text { Commitment to } \\
\text { Single Fund }\end{array}$ & $\begin{array}{c}\text { Risk/Return } \\
\text { Ratio in CEE }\end{array}$ \\
\hline 0 & N & 40 & 34 & 31 \\
& Mean & 34.573 & 10.559 & 4.90 \\
& Std. Deviation & 39.6687 & 18.1412 & 1.399 \\
\hline 1 & N & 27 & 26 & 20 \\
& Mean & 87.185 & 14.692 & 4.20 \\
& Std. Deviation & 26.5751 & 12.1845 & 1.105 \\
\hline & Mann-Whitney U & 178.000 & 261.000 & 214.000 \\
& Z & -4.854 & -2.743 & -1.901 \\
& Asymp. Sig. (2-tailed) & .000 & .006 & .057 \\
\hline
\end{tabular}

The proposed differences are supported by the data. First, the funds-of-funds do not greatly differ from the specialized funds we considered in the previous sample partition test. They are characterized by an average commitment to the VC/PE asset class of $87.2 \%$ and a median of even 100\% which are significantly different from the commitments of the non-funds of funds. This suggests that the majority of the funds-of-funds are, at the same time, focused on VC/PE and hence, in fact, VC/PE Funds-of-Funds. However, analyzing the data more closely reveals that 9 funds with 100\% VC/PE exposure do not qualify themselves as funds of funds, and inversely, 5 funds identify themselves as funds-of-funds but each have a very low VC/PE exposure. Whatever the case may be, it can be argued that, once again, we identify a more specialized type of investor, and find that, while their funds under management are not significantly larger than those of their peers, they are looking for a higher level of commitment in general and, hence, raise the minimum commitment level. Furthermore, the funds-of-funds demand more of their investees, as reflected by less satisfaction with the CEE risk/return ratio (this result is based on a 0.57 significance level). This is probably due to the fact that, as mentioned before, funds-of-funds have to rely heavily on the agents in the subsequent chain of diversification.

Summarizing the results of partitioning the sample, we claim that there are only minor differences in the capital allocation strategies and perceptions of certain sub-groups of the institutional investors. The strategies and perceptions do not vary to such an extent that our results get meaningfully biased towards a particular sub-group in our sample. Hence, we propose that the results are representative for the whole population of limited partners.

\subsection{CEE Investment Decision Determinants}

One major distinction within our analyses can be made by the actual investment decision in CEE. We assume that an investor's final decision to allocate funds for VC/PE partnerships in the CEE region is dependent on certain characteristics. These characteristics can be best addressed by logit regressions that directly relate the binary dependent variable of the investment decision to several decision parameters: 
For a binary variable $\mathrm{Y}$ and a vector of $\mathrm{p}$ explanatory variables $\mathrm{x}$ at values $\mathrm{X}=\left(\mathrm{x}_{1}, \ldots, \mathrm{x}_{\mathrm{p}}\right)$, let

$\pi(\mathbf{x})=P(Y=1 \mid \mathbf{X}=\mathbf{x})=1-P(Y=0 \mid \mathbf{X}=\mathbf{x})$

where $\mathrm{P}(. .$.$) measures the probability of an event. The logit regression model then is:$

$\operatorname{logit}[\pi(\mathbf{x})]=\log \frac{\pi(\mathbf{x})}{1-\pi(\mathbf{x})}=\beta_{0}+\beta_{1} x_{1}+\beta_{2} x_{2}+\ldots+\beta_{p} x_{p}$

The intercept parameter $\beta_{0}$ is not of particular interest, but can be interpreted as $\log$ odds if the explanatory variables are null. The parameter $\beta_{\mathrm{i}}$ refers to the effect of $\mathrm{x}_{\mathrm{i}}$ on the $\log$ odds of $\mathrm{Y}=1$, controlling for the other $\mathrm{x}_{\mathrm{j}}$. Exponentiation (1) shows that $\exp \left(\beta_{\mathrm{i}}\right)$ is the multiplicative effect on the odds of a 1-unit increase in $x_{i}$, at fixed levels of the other $x_{j}$.

Using logit regressions we comprehensively test several hypotheses, and below we focus on those with significant results only. The dependent variable in all of the following cases is whether or not an LP has exposure in the region. We define the hypotheses, present the statistical tests of the models, and conclude the findings. Unfortunately, as mentioned before, the number of valid responses to the particular groups of survey questions and the response behavior among the survey participants differs largely. As an undesirable consequence, the data set for multivariate logit regressions (where a complete matrix of regressors is required) is considerably reduced. Hence, we perform bivariate logit regressions in the cases with otherwisereduced datasets, and a multivariate logit regression for the analysis of the driving socioeconomic factors, where a satisfying matrix of regressors is available.

Hypotheses No. 1:

H0: LPs invest in CEE countries irrespective of their level of satisfaction about the historical performance in that region.

H1: LPs invest in CEE countries because they are satisfied with the historical performance and expect extrapolation.

The analysis is based on 47 observations, of which 33 LPs have exposure in CEE. It results in a significant parameter of investor satisfaction with historical risk and return ratios, the HO hypothesis is rejected.

\section{Table 10}

Logit Regression Results (R-R-eval, Independent Variable is the Evaluation of the Historical Risk/Return Ratio in CEE)

\begin{tabular}{|l|c|c|c|c|c|c|c|}
\hline & B & S.E. & Wald & Sig. & Exp(B) & Chi-square & Model-Sig. \\
\hline R-R-eval &, 539 &, 256 & 4,450 &, $\mathbf{0 3 5}$ & 1,715 & \multirow{2}{*}{5,009} & \multirow{2}{0}{$\mathbf{0 2 5}$} \\
Constant & $-1,529$ & 1,140 & 1,800 &, 180 &, 217 & & \\
\hline
\end{tabular}

The exponential of the parameter $\beta_{1}$, $\exp \left(\beta_{1}\right)$, is the odds ratio of maintaining exposure in the CEE region. On the basis of these findings, it can be argued that an increase of one point in our Likert scale in the answer about investor satisfaction with the historical performance in CEE countries increases the odds of investment in the region. For an investor who is indifferent as to whether or not to invest, i.e., with a probability of 50\% or an odds of 1 , all else being equal, an increase of one point in the level of satisfaction with the historical performance, leads to a 
new odds ratio of 1.715 and, hence, to an investment probability of $1.715 /(1+1.715)=63.2 \%$. With this result we conclude that the historic performance greatly influences decisions about future allocations. This supports the findings in literature on the tendency of extrapolation of performance results, e.g., in Friend and Vickers (1965), or Lakonishok et al. (1994). However, this is a rationale approach considering the findings on performance persistence in Grinblatt and Titman (1992), Elton et al. (1996), and especially, and most notably, those that prove the strong performance persistence of good and poor GPs in the VC/PE capital market segment reported by Kaplan and Schoar (2005).

Hypotheses no. 2:

H0: LPs invest in the CEE region irrespective of their level of knowledge about the countries.

H1: Only LPs with sufficient knowledge invest in the CEE region.

The analysis is based on 65 observations, of which 32 LPs have exposure in CEE, and significant results show that, in fact, regional knowledge determines the investment decision. Hence, the Ho hypothesis is rejected.

\section{Table 11}

Logit Regression Results (Knowl, Independent Variable is the Knowledge about the CEE Region)

\begin{tabular}{|l|c|r|c|c|r|r|c|}
\hline & \multicolumn{1}{|c|}{ B } & \multicolumn{1}{c|}{ S.E. } & Wald & Sig. & Exp(B) & Chi-square & Model-Sig. \\
\hline Knowl &, 787 &, 225 & 12,292 &, 000 & 2,198 & 17,184 &, 000 \\
Constant & $-3,468$ & 1,031 & 11,311 & $\mathbf{, 0 0 1}$ &, 031 & & \\
\hline
\end{tabular}

The result proves a very strong correlation between informed investors and the decision to allocate, with an odds ratio of 2.198 per point on our Likert scale. The likelihood of investing in the region becomes, all else being equal, $2.198 /(1+2.198)=68.7 \%$ for an otherwise indifferent investor who increases his knowledge about the region by one point on our Likert scale. Limited Partners obviously do not naively diversify, but make allocation decisions based on regional knowledge. They do not follow a $1 / \mathrm{n}$ heuristic as discussed in Benartzi and Thaler (2001), and only invest if they have sufficiently regional expertise. This strong result is also confirmed by Fernandes (2004) who emphasizes the need for elaborate country selection strategies in order to outperform benchmarks. It also underscores the benefit of informational campaigns and research publications that can help emerging economies attract international institutional capital by the transfer of knowledge.

Hypotheses No. 3:

H0: Institutional investors invest in the CEE region irrespective of their perceptions of (other) emerging markets.

H1: Investors with exposure in CEE are attracted by the region itself and also by other emerging regions. There is a tendency for "emerging market investing."

Once more, unfortunately, bivariate analyses have to be performed for the different emerging regions (Africa, CEE, China, CIS, India, Latin America, and Southeast Asia) to omit the problem of dealing with a much reduced data set caused by missing responses from individual 
participants for some of the regions. The HO hypothesis has to be accepted for China, India, Latin America, and Southeast Asia, and has to be rejected for Africa, CEE, and CIS.

In the case of Africa, we observe 64 responses, of which 33 investors have exposure in CEE. The analysis reveals that the perception of Africa has a significant influence on the decision of allocations to CEE.

\section{Table 12}

Logit Regression Results (AttrAfr, Independent Variable is the Evaluation of Africa's Attractiveness)

\begin{tabular}{|l|c|c|c|c|c|c|c|}
\hline & B & S.E. & Wald & Sig. & Exp(B) & Chi-square & Model-Sig. \\
\hline AttrAfr &, 451 &, 227 & 3,965 &, 046 & 1,571 & \multirow{2}{*}{4,619} & \multirow{2}{0}{032} \\
Constant &,- 888 &, 529 & 2,822 &, 093 &, 411 & & \\
\hline
\end{tabular}

In the case of CEE itself, we observe 68 responses, of which 35 investors have exposure in CEE. As expected, the analysis reveals that perceptions of the attractiveness of the CEE region have a strong influence on the decision of allocations to it.

\section{Table 13}

Logit Regression Results (AttrCEE, Independent Variable is the Evaluation of CEE's Attractiveness)

\begin{tabular}{|l|c|c|c|c|c|c|c|}
\hline & B & S.E. & Wald & Sig. & Exp(B) & Chi-square & Sig. \\
\hline AttrCEE &, 610 &, 251 & 5,914 & $\mathbf{, 0 1 5}$ & 1,841 & \multirow{2}{*}{6,942} & \multirow{2}{*008}{} \\
Constant & $-2,976$ & 1,276 & 5,434 & $\mathbf{, 0 2 0}$ &, 051 & & \\
\hline
\end{tabular}

For the CIS region, we observe 66 responses, of which 35 investors with exposure in CEE. The analysis reveals that the perception of the attractiveness of the CIS region also has a significant influence on the decision of allocations to CEE.

\section{Table 14}

Logit Regression Results (AttrCIS, Independent Variable is the Evaluation of CIS' Attractiveness)

\begin{tabular}{|l|c|c|c|c|c|c|c|}
\hline & B & S.E. & Wald & Sig. & Exp(B) & Chi-square & Model-Sig. \\
\hline AttrCIS &, 561 &, 209 & 7,181 & $\mathbf{, 0 0 7}$ & 1,753 & \multirow{2}{*}{8,519} & \multirow{2}{*004}{} \\
Constant & $-1,920$ &, 796 & 5,810 & $\mathbf{, 0 1 6}$ &, 147 & & \\
\hline
\end{tabular}

As expected, the decision to allocate funds to the CEE region is determined primarily by the evaluation of the attractiveness of the CEE region itself (odds ratio of 1.841); however, it is also correlated with the perceptions of Africa (odds ratio of 1.571) and the CIS region (odds ratio of 1.753). The decision about maintaining exposure in CEE is independent of perceptions of the other emerging regions, namely China, India, Latin America, and Southeast Asia. While thecorrelation with perceptions of Africa is harder to explain, the similarities between the CEE and the CIS region are clear. These two markets, geographically close, are considered to be similar in terms of being former communist countries that have evolved to open market economies with or without accession to the European Union. Probably, investors in CEE also maintain exposure in CIS. Unfortunately, this issue is not covered by our survey questions. 
However, we prove that there is a tendency for "emerging market investing," i.e., investors that have exposure in CEE are also attracted by other emerging regions.

Hypotheses No. 4:

H0: Investors invest in the CEE region irrespective of their assessment of key socioeconomic conditions in the region, such as economic activity, local capital markets, taxation, investor protection, the social environment, and entrepreneurial activities.

H1: Investors closely link their decision to invest in CEE to the selection criteria mentioned in HO.

The multivariate logit regression on the above-mentioned six parameters is based on 60 observations, of which 30 LPs have exposure in CEE. The results show a significant parameter of entrepreneurial opportunities only. Hence, the HO hypothesis is rejected for entrepreneurial opportunities, but it is accepted for all the other key driving factors.

\section{Table 15}

Logit Regression Results (The Independent Variables are Evaluations of the: EcoAct - Economic Activity, CapMark - Capital Market, Taxation - Taxation, InvProt - Investor Protection, SocEnv Social Environment, and EntrOpp - Entrepreneurial Opportunities)

\begin{tabular}{|l|c|r|r|r|r|r|r|}
\hline & \multicolumn{1}{|c|}{ B } & \multicolumn{1}{|c|}{ S.E. } & Wald & Sig. & Exp(B) & Chi-square & Model-Sig. \\
\hline EcoAct &,- 036 &, 442 &, 007 &, 934 &, 964 & & \\
CapMark &,- 651 &, 453 & 2,064 &, 151 &, 522 & & \\
Taxation &,- 137 &, 376 &, 132 &, 716 &, 872 & & \\
InvProt &, 438 &, 387 & 1,275 &, 259 & 1,549 & 18,528 &, 005 \\
SocEnv &,- 348 &, 453 &, 592 &, 442 &, 706 & & \\
EntrOpp & 1,331 &, 411 & 10,473 &, 001 & 3,787 & & \\
Constant & $-3,466$ & 1,918 & 3,265 &, 071 &, 031 & & \\
\hline
\end{tabular}

The evaluation of the entrepreneurial opportunities very strongly determines the decision to allocate funds in the CEE region. All else being equal, an increase of 1 point on the Likert scale raises the probability of investing for an otherwise indifferent investor to $79.1 \%$. LPs decide to invest in CEE because of expected entrepreneurial opportunities. However, there is no other parameter that finally determines the investment decision. Hence, investors are not sufficiently satisfied with the other key driving factors used in the model. This finding reveals possible room for improvement of the other driving forces in order to attract more international institutional capital for VC/PE funds.

Hypotheses No. 5:

H0: LPs invest in the region irrespective of perceptions they have about the quality of local fund management teams.

H1: LPs only invest if they are confident about the quality of the local fund management teams. 
The bivariate logit regression is based on 62 observations. Of the respondents, 30 have exposure in CEE. The regression results show a significant parameter for the evaluation of quality of local GPs. Hence, the Ho hypothesis is rejected.

\section{Table 16}

Logit Regression Results (GPqual, Independent Variable is the Evaluation of the Quality of CEE Fund Management Teams)

\begin{tabular}{|l|c|c|c|c|c|c|c|}
\hline & B & S.E. & Wald & Sig. & Exp(B) & Chi-square & Sig. \\
\hline GPqual & 1,082 &, 352 & 9,429 &, 002 & 2,950 & \multirow{2}{*}{13,787} & \multirow{2}{*}{, 000} \\
\hline Constant & $-4,808$ & 1,585 & 9,208 &, 002 &, 008 & & \\
\hline
\end{tabular}

LPs that evaluate the quality of local CEE teams as good are more likely to invest. For indifferent investors, an increase in their evaluation of the quality of GPs by one point on the Likert scale, all else being equal, will raise the likelihood of investing to $2.950 /(1+2.950)=74.7 \%$. The strong influence of this parameter emphasizes the fact that the funded teams in CEE must be regarded as very professional. This finding also highlights the desire of LPs to engage with top-tier GPs only. Kaplan and Schoar (2005) point out the existence of individual management teams who continue to perform strongly and that, therefore, searching for good teams is worthwhile. Lerner and Schoar (2004) show that LPs should optimally sort out poorly performing GPs and commit to good ones only. However, not all LPs screen the GPs sufficiently. Lerner et al. (2005) find that endowments and public pension funds are more sophisticated in their selection processes, and use their insider information, and are thus better able to forecast performance on follow-on funds. However, with our small sample of endowments and pension funds, we are unfortunately not able to follow up on this interesting issue.

\section{Conclusions}

The Central Eastern European countries offer a large range of opportunities to institutional investors. Expectations for economic growth for the coming decades are promising, and institutional as well as societal prerequisites in the European Union accession countries are, in theory, favorable. Nevertheless, the supply of risk capital is relatively poor in relation to the opportunities in this region compared to other countries. This is surprising and presents the challenge of identifying the obstacles to more institutional investment in Venture Capital and Private Equity funds in CEE. With a questionnaire sent out to 1,079 (potential) limited partners based all over the world we address investor perceptions about the region, and link their institutional settings and exposure with their regional perceptions. We prove that our sample sufficiently represents the population of limited partners, arguing that there are no (statistically significant) meaningful differences regarding their perceptions and allocation decision criteria.

We show that institutional investors regard CEE as a very attractive region, ranking equally with India, and slightly higher than China. Among CEE, Poland is the most attractive country, followed by the Czech Republic and Hungary. We group possible allocation determinants into six criteria: Economic activity, capital market, taxation, property rights protection, social environment and entrepreneurial activity, and prove that, when assessing CEE, the institutional investors regard economic activity and the entrepreneurial opportunities there as favorable. Conversely, and this is a very important finding, they do not feel comfortable about the most 
prominent criteria discussed in literature, which is the protection of their claims. Thereby, it is of no relevance that investors might not be well-enough informed about the actual property rights protection legislature and enforcement possibilities in CEE. It is a fact, and this should alert policymakers, that they are not comfortable with the current situation, and hence, might refrain from investment. Simple means, such as greater transparency of property rights protection and informational campaigns might lead to an increase of risk capital supply.

Investors with exposure in CEE are satisfied with the historic performance of their allocated funds, have a good knowledge of the region, and are also attracted by other emerging Venture Capital and Private Equity markets. These investors appreciate the entrepreneurial opportunities and the quality of local fund management teams in CEE. However, they are, as well as the other investors without exposure in CEE, not satisfied with the protection of their property rights.

Our results add to the current literature on the importance of effective property rights protection in the competition for international institutional capital. They further contribute to more transparency of the asset allocation processes of institutional investors and to a better understanding of investment obstacles in CEE, and other emerging regions. Local policymakers should henceforth be able to detect weaknesses in their countries regarding the investor allocation criteria and to exploit this room for improvement to spur regional Venture Capital and Private Equity markets, and hence resources, for financing innovation, entrepreneurship, employment, and growth. 


\section{References}

Armour, J. and D. Cumming (2006), "The legislative road to Silicon Valley," Oxford Economic Papers, Vol. 58, pp. 596-635.

Balboa, M. and J. Martí (2003), "An integrative approach to the determinants of private equity fundraising,” SSRN working paper 493344.

Baughn, C. C. and K. E. Neupert (2003), "Culture and national conditions facilitating entrepreneurial start-ups,” Journal of International Entrepreneurship, Vol. 1, pp. 313-330.

Barrel, R. and D. Holland (2000), "Foreign direct investment and enterprise restructuring in Central Europe," Economics of Transition, Vol. 8, No. 2, pp. 477-504.

Benartzi, S. and R. H. Thaler (2001), "Naive diversification strategies in defined contribution saving plans," American Economic Review, Vol. 91, pp. 79-98.

Black, B. and R. Gilson (1998), "Venture capital and the structure of capital markets: Banks versus stock markets," Journal of Financial Economics, Vol. 47, pp. 243-277.

Blanchard, O. J. (1997), “The medium run,” Brookings Papers on Economic Activity, pp. 89-158.

Bliss, R. T. (1999), "A venture capital model for transitioning economies: the case of Poland," Venture Capital, Vol. 1, pp. 241-257.

Bruce, D. (2000), "Effects of the United States' tax system on transition into self-employment," Labor Economics, Vol. 7, pp. 545-574.

Bruce, D. (2002), "Taxes and entrepreneurial endurance: Evidence from the self-employed," National Tax Journal, Vol. 55, pp. 5-24.

Chan-Lau, J. A. (2004), “Pension funds and emerging markets,” IMF working paper 04/181.

Chemla, G. (2005), "The determinants of investment in private equity and venture capital: evidence from American and Canadian pension funds," SSRN working paper 556421.

Chu, P. and R. D. Hisrich (2001), "Venture Capital in an economy in transition," Venture Capital, Vol. 3, pp. 169-182.

Cullen, J. B. and R. H. Gordon (2002), "Taxes and entrepreneurial activity: Theory and evidence for the U.S.," NBER working paper 9015.

Cumming, D., G. Flemming, and A. Schwienbacher (2006a), "Legality and venture capital exits," Journal of Corporate Finance, Vol. 12, pp. 214-245.

Cumming, D., D. Schmidt, and U. Walz (2006b), "Legality and venture governance around the world," SSRN working paper 537243.

Cumming, D. and S. Johan (2007, "Regulatory harmonization and the development of private equity markets," Journal of Banking and Finance (forthcoming).

Da Rin, M., G. Nicodano, and A. Sembelli (2005), "Public policy and the creation of active venture capital markets,” European Central Bank working paper No. 430.

Desai, M., P. Gompers, and J. Lerner (2006), "Institutions and entrepreneurial firm dynamics: Evidence from Europe,” Harvard NOM research paper 03-59. 
Djankov, S., R. La Porta, F. López de Silanes, and A. Shleifer (2003), “Courts,” Quarterly Journal of Economics, Vol. 118, pp. 453-517.

Djankov, S., R. La Porta, F. López de Silanes, and A. Shleifer (2005), "The law an economics of self-dealing," NBER working paper 11883.

EBRD (2005), “Transition Report 2005: Business in Transition,” London.

Elton, E. J., M. Gruber, and C. J. Blake (1996), "The persistence of risk-adjusted mutual fund performance," Journal of Business, Vol. 69, pp. 133-157.

EVCA (2004), "EVCA yearbook 2004 - Annual survey of Pan-European private equity \& venture capital activity,” EVCA European Venture Capital Association, Brussels.

EVCA (2005), "EVCA yearbook 2005 - Annual survey of Pan-European private equity \& venture capital activity,” EVCA European Venture Capital Association, Brussels.

EVCA (2006), "EVCA yearbook 2006 - Annual survey of Pan-European private equity \& venture capital activity," EVCA European Venture Capital Association, Brussels.

Farag, H., U. Hommel, P. Witt, and M. Wright (2004), "Contracting, monitoring, and exiting venture investments in transitioning economies: a comparative analysis of Eastern European and German markets," Venture Capital, October 2004, Vol. 6, No. 4, pp. 257-282.

Fernandes, N. (2004), "What level of portfolio disaggregation in emerging markets?," Journal of Portfolio Management, Vol. 31, pp. 41-49.

Friend, I. and D. Vickers (1965), "Portfolio selection and investment performance," Journal of Finance, Vol. 20, pp. 391-415.

Glaeser, E.L., S. Johnson, and A. Shleifer (2001), "Coase vs. the Coasians," Quarterly Journal of Economics, Vol. 116, pp. 853-899.

Gompers, P. and J. Lerner (1998), "What drives venture fundraising?," Brooking Papers on Economic Activity, Microeconomics, pp. 149-192.

Gompers, P. and J. Lerner (2000), "Money chasing deals? The impact of funds inflows on the valuation of private equity investments," Journal of Financial Economics, Vol. 55, pp. 281-325.

Greene, P.G. (1998), “Dimensions of perceived entrepreneurial obstacles," in P. Reynolds (ed.): "Frontiers of entrepreneurship research," Babson Park: Center for Entrepreneurial Studies, Babson College, pp. 48-49.

Grinblatt, M. and S. Titman (1992), “The persistence of mutual fund performance," Journal of Finance, Vol. 47, pp. 1977-1984.

Jeng, L. A. and Ph. C. Wells (2000), "The deteminants of venture capital funding: evidence across countries," Journal of Corporate Finance, Vol. 6, pp. 241-289.

Johnson, S. H., J. McMillan, and C. M. Woodruff (1999), "Property rights, finance and entrepreneurship," SSRN working paper 198409. 
Kaminsky, G. L., R. K. Lyons, and S. L. Schmuckler (2001), "Mutual fund investment in emerging markets: An overview," World Bank Economic Review, Vol. 15, pp. 315-340.

Kaplan, S. N. and A. Schoar (2005), "Private equity performance: Returns, persistence, and capital flows,” Journal of Finance, Vol. 60, pp. 1791-1823.

Karsai, J., M. Wright, Z. Dudzinski, and J. Morovic (1998), "Screening and valuing venture capital investmenst: evidence from Hungary, Poland and Slovakia," Entrepreneurship \& Regional Development, Vol. 10, pp. 203-224.

Klonowski, D. (2005), "How do venture capitalists make investment decisions in Central and Eastern Europe?," Brandon University working paper.

Knack, S. and P. Keefer (1995), "Institutions and economic performance: Cross-country tests using alternative institutional measures,” Economics and Politics, Vol. 7, pp. 207-228.

Köke, F. J. (1999), “Institutional Investment in Central and Eastern Europe: Investment criteria of Western portfolio managers," ZEW Discussion Paper no. 99-37.

Kolodko, G. W. (2000), "Globalisation and catching-up: From recession to growth in transition economies,” IMF working paper 00/100.

Konings, J. (2001), "The effects of foreign direct investment on domestic firms," Economics of Transition, Vol. 9, No. 3, pp. 619-633.

Lakonishok, J., A. Shleifer, and R. W. Vishny (1994), “Contrarian investment, extrapolation and risk,” Journal of Finance, Vol. 49, pp. 1541-1578.

La Porta, R., F. López de Silanes, A. Shleifer, and R. Vishny (1997), "Legal determinants of external finance," Journal of Finance, Vol. 52, pp. 1131-1150.

La Porta, R., F. López de Silanes, A. Shleifer, and R. Vishny (1998), “Law and financ,” Journal of Political Economy, Vol. 106, pp. 1113-1155.

La Porta, R., F. López de Silanes, A. Shleifer, and R. Vishny (2002), "Investor protection and corporate valuation," Journal of Finance, Vol. 57, pp. 1147-1170.

Lazear, E. P. (1990), “Job security provisions and employment,” Quarterly Journal of Economics, Vol. 105, pp. 699-726.

Lee, S. M. and S.J. Peterson (2000), "Culture, entrepreneurial orientation and global competitiveness," Journal of World Business, Vol. 35, pp. 401-416.

Lerner, J. and A. Schoar (2004), "The illiquidity puzzle: Theory and evidence from private equity," Journal of Financial Economics, Vol. 72, pp. 3-40.

Lerner, J. and A. Schoar (2005), "Does legal enforcement affect financial transactions? The contractual channel in private equity," Quarterly Journal of Economics, Vol. 120, pp. 223-246.

Lerner, J., A. Schoa, and W. Wong (2005), "Smart institutions, foolish choices? The limited partner performance puzzle,” MIT working paper 4523-05.

Mauro, P. (1995), “Corruption and growth," Quarterly Journal of Economics, Vol. 110, pp. 681-712. 
Megginson, W. (2004), "Toward a global model of venture capital?," Journal of Applied Corporate Finance, Vol. 16, pp. 89-107.

Michelacci, C. and J. Suárez (2004), "Business creation and the stock market," Review of Economic Studies, Vol. 71, pp. 459-481.

Resmini, L. (2000), "The determinants of foreign direct investment in CEECs," Economics of Transition, Vol. 8, No. 3, pp. 665-689.

Romain, A. and B. van Pottelsberghe de la Potterie (2004), "The determinants of venture capital: A panel analysis of 16 OECD countries," Université Libre de Bruxelles, working paper WPCEB 04/015.

Sapienza, H., S. Manigart, and W. Vermeir (1996), "Venture capitalist governance and value added in four countries," Journal of Business Venturing, Vol. 11, pp. 439-469.

Schertler, A. (2003), "Driving forces of venture capital investments in Europe: A dynamic panel data analysis," European Integration, Financial Systems and Corporate Performance (EIFC) working paper No. 03-27, United Nations University.

Schöfer, P. and R. Leitinger (2002), "Framework for venture capital in the accession countries to the European Union," SSRN working paper 314412.

Süppel, R. (2003), "Comparing economic dynamics in the EU and CEE accession countries," European Central Bank working paper 267.

Svensson, J. (1998), "Investment, property rights and political instability: Theory and evidence," European Economic Review, Vol. 42, pp. 1317-1341.

Wagner, M. and J. Hlouskova (2005), "CEEC growth projections: Certainly necessary and necessarily uncertain," Economics of Transition, Vol. 13, No. 3, pp. 341-372.

Wilken, P. H. (1979), “Entrepreneurship: A comparative and historical Study,” Norwood.

Yudaeva, K., K. Kozlov, N. Melentieva, and N. Ponomareva (2003), "Does foreign ownership matter?," Economics of Transition, Vol. 11, No. 3, pp. 383-409. 


\section{Appendix}

\section{Appendix 1}

Wilcoxon Signed Rank Test on the Attractiveness of Different Emerging Regions

The ranks and test statistics are presented for the tests comparing Africa with the other regions. For all the other tests we present the test statistics only for the save of space.

Ranks:

\begin{tabular}{|c|c|c|c|c|}
\hline & & $\mathbf{N}$ & Mean Rank & Sum of Ranks \\
\hline \multirow[t]{4}{*}{ CEE - Africa } & Negative Ranks & 1 & 5,00 & 5,00 \\
\hline & Positive Ranks & 65 & 33,94 & 2206,00 \\
\hline & Ties & 3 & & \\
\hline & Total & 69 & & \\
\hline \multirow[t]{4}{*}{ China - Africa } & Negative Ranks & 5 & 18,70 & 93,50 \\
\hline & Positive Ranks & 59 & 33,67 & 1986,50 \\
\hline & Ties & 2 & & \\
\hline & Total & 66 & & \\
\hline \multirow[t]{4}{*}{ CIS - Africa } & Negative Ranks & 6 & 25,00 & 150,00 \\
\hline & Positive Ranks & 52 & 30,02 & 1561,00 \\
\hline & Ties & 9 & & \\
\hline & Total & 67 & & \\
\hline \multirow[t]{4}{*}{ India - Africa } & Negative Ranks & 3 & 5,50 & 16,50 \\
\hline & Positive Ranks & 63 & 34,83 & 2194,50 \\
\hline & Ties & 2 & & \\
\hline & Total & 68 & & \\
\hline \multirow[t]{4}{*}{ Latin America - Africa } & Negative Ranks & 4 & 25,13 & 100,50 \\
\hline & Positive Ranks & 44 & 24,44 & 1075,50 \\
\hline & Ties & 16 & & \\
\hline & Total & 64 & & \\
\hline \multirow[t]{4}{*}{ South East Asia - Africa } & Negative Ranks & 3 & 18,50 & 55,50 \\
\hline & Positive Ranks & 52 & 28,55 & 1484,50 \\
\hline & Ties & 3 & & \\
\hline & Total & 58 & & \\
\hline
\end{tabular}

Test Statistics(b): Africa vs. other Emerging Economies

\begin{tabular}{|l|r|r|r|r|r|r|}
\hline & $\begin{array}{c}\text { CEE - } \\
\text { Africa }\end{array}$ & China - Africa & CIS - Africa & India - Africa & $\begin{array}{c}\text { Latin America } \\
\text { - Africa }\end{array}$ & $\begin{array}{c}\text { Southeast Asia - } \\
\text { Africa }\end{array}$ \\
\hline Z & $-7,081(\mathrm{a})$ & $-6,377(\mathrm{a})$ & $-5,521(\mathrm{a})$ & $-6,998(\mathrm{a})$ & $-5,086(\mathrm{a})$ & $-6,038(\mathrm{a})$ \\
Asymp. Sig. (2-tailed) & $\mathbf{, 0 0 0}$ & $\mathbf{0 0 0}$ & $\mathbf{, 0 0 0}$ & $\mathbf{0 0 0 0}$ & $\mathbf{0 0 0 0}$ & $\mathbf{0 0 0 0}$ \\
\hline
\end{tabular}

a Based on negative ranks.

b Wilcoxon Signed Ranks Test. 


\section{Appendix 1 (continued)}

Test Statistics(c): CEE vs. other Emerging Economies

\begin{tabular}{|l|c|c|c|c|c|}
\hline & & & Latin America & Southeast \\
& China - CEE & CIS - CEE & India - CEE & $\begin{array}{c}\text { - CEE } \\
\text { Asia - CEE }\end{array}$ \\
\hline Z & $-1,404(\mathrm{a})$ & $-5,196(\mathrm{a})$ &,$- 650(\mathrm{~b})$ & $-6,321(\mathrm{a})$ & $-3,158(\mathrm{a})$ \\
Asymp. Sig. (2-tailed) &, 160 & $\mathbf{, 0 0 0}$ &, 516 &, $\mathbf{0 0 0}$ &, $\mathbf{0 0 2}$ \\
\hline
\end{tabular}

a Based on positive ranks.

b Based on negative ranks.

c Wilcoxon Signed Ranks Test.

Test Statistics(c): China vs. other Emerging Economies

\begin{tabular}{|c|c|c|c|c|}
\hline & CIS - China & India - China & $\begin{array}{c}\text { Latin America } \\
\text { - China }\end{array}$ & $\begin{array}{c}\text { Southeast } \\
\text { Asia - China }\end{array}$ \\
\hline Z & $-3,503(a)$ & $-2,697(b)$ & $-5,170(a)$ & $-1,718(a)$ \\
\hline Asymp. Sig. (2-tailed) & ,000 &, 007 &, 000 & ,086 \\
\hline
\end{tabular}

Test Statistics(c): CIS vs. other Emerging Economies

\begin{tabular}{|l|c|r|r|}
\hline & India - CIS & $\begin{array}{c}\text { Latin America } \\
- \text { CIS }\end{array}$ & $\begin{array}{r}\text { Southeast } \\
\text { Asia - CIS }\end{array}$ \\
\hline Z & $-4,781(\mathrm{a})$ & $-2,205(\mathrm{~b})$ & $-1,960(\mathrm{a})$ \\
Asymp. Sig. (2-tailed) & $\mathbf{, 0 0 0}$ & $\mathbf{, 0 2 7}$ & $\mathbf{0 5 0}$ \\
\hline
\end{tabular}

a Based on negative ranks.

b Based on positive ranks.

c Wilcoxon Signed Ranks Test.

Test Statistics(b): India vs. other Emerging Economies

\begin{tabular}{|l|c|c|}
\hline & $\begin{array}{c}\text { Latin America } \\
- \text { India }\end{array}$ & $\begin{array}{c}\text { Southeast } \\
\text { Asia - India }\end{array}$ \\
\hline Z & $-6,314(\mathrm{a})$ & $-3,973(\mathrm{a})$ \\
Asymp. Sig. (2-tailed) & $\mathbf{, 0 0 0}$ & $\mathbf{, 0 0 0}$ \\
\hline
\end{tabular}

a Based on positive ranks.

b Wilcoxon Signed Ranks Test.

Test Statistics(b): Southeast Asia vs. Latin America

\begin{tabular}{|l|c|}
\hline & $\begin{array}{c}\text { Southeast Asia } \\
\text { - Latin America }\end{array}$ \\
\hline Z & $-4,402(a)$ \\
Asymp. Sig. (2-tailed) &, $\mathbf{0 0 0}$ \\
\hline \\
a Based on negative ranks. \\
b Wilcoxon Signed Ranks Test.
\end{tabular}




\section{Appendix 2}

Wilcoxon Signed Rank Test on the Attractiveness of the Individual CEE Countries

Test Statistics(c): Baltic States vs. other CEE Countries

\begin{tabular}{|l|r|r|r|r|r|r|r|}
\hline & $\begin{array}{c}\text { Bulgaria - } \\
\text { Baltic } \\
\text { States }\end{array}$ & $\begin{array}{c}\text { Czech } \\
\text { Republic }- \\
\text { Baltic } \\
\text { States }\end{array}$ & $\begin{array}{c}\text { Hungary - } \\
\text { Baltic } \\
\text { States }\end{array}$ & $\begin{array}{c}\text { Poland - } \\
\text { Baltic } \\
\text { States }\end{array}$ & $\begin{array}{c}\text { Romania - } \\
\text { Baltic } \\
\text { States }\end{array}$ & $\begin{array}{c}\text { Slovakia - } \\
\text { Baltic } \\
\text { States }\end{array}$ & $\begin{array}{c}\text { Slovenia - } \\
\text { Baltic } \\
\text { States }\end{array}$ \\
\hline $\begin{array}{l}\text { Z } \\
\begin{array}{l}\text { Asymp. Sig. (2- } \\
\text { tailed) }\end{array}\end{array}$ & $-3,206(\mathrm{a})$ & $-2,884(\mathrm{~b})$ & $-1,580(\mathrm{~b})$ & $-4,439(\mathrm{~b})$ &,$- 375(\mathrm{a})$ &,$- 345(\mathrm{a})$ & $-1,340(\mathrm{a})$ \\
\end{tabular}

a Based on positive ranks.

b Based on negative ranks.

c Wilcoxon Signed Ranks Test.

Test Statistics(b): Bulgaria vs. other CEE Countries

\begin{tabular}{|l|r|r|r|r|r|r|}
\hline & $\begin{array}{c}\text { Czech } \\
\text { Republic - } \\
\text { Bulgaria }\end{array}$ & $\begin{array}{c}\text { Hungary - } \\
\text { Bulgaria }\end{array}$ & $\begin{array}{c}\text { Poland - } \\
\text { Bulgaria }\end{array}$ & $\begin{array}{c}\text { Romania - } \\
\text { Bulgaria }\end{array}$ & $\begin{array}{c}\text { Slovakia - } \\
\text { Bulgaria }\end{array}$ & $\begin{array}{c}\text { Slovenia - } \\
\text { Bulgaria }\end{array}$ \\
\hline Z & $-4,793(a)$ & $-3,801(a)$ & $-5,745(a)$ & $-3,048(a)$ & $-2,750(a)$ & $-1,658(a)$ \\
Asymp. Sig. (2-tailed) & $\mathbf{, 0 0 0}$ & $\mathbf{, 0 0 0}$ & $\mathbf{, 0 0 0}$ & $\mathbf{, 0 0 2}$ & $\mathbf{, 0 0 6}$ &, 097 \\
\hline
\end{tabular}

Based on negative ranks.

b Wilcoxon Signed Ranks Test.

Test Statistics(c): Czech Republic vs. other CEE Countries

\begin{tabular}{|l|r|r|r|r|r|}
\hline & $\begin{array}{c}\text { Hungary - } \\
\text { Czech } \\
\text { Republic }\end{array}$ & $\begin{array}{c}\text { Poland - } \\
\text { Czech } \\
\text { Republic }\end{array}$ & $\begin{array}{c}\text { Romania - } \\
\text { Czech } \\
\text { Republic }\end{array}$ & $\begin{array}{c}\text { Slovakia - } \\
\text { Czech } \\
\text { Republic }\end{array}$ & $\begin{array}{c}\text { Slovenia - } \\
\text { Czech } \\
\text { Republic }\end{array}$ \\
\hline Z & $-1,392(a)$ & $-2,960(b)$ & $-2,658(a)$ & $-3,590(a)$ & $-3,690(a)$ \\
Asymp. Sig. (2-tailed) &, 164 &, $\mathbf{0 0 3}$ &, $\mathbf{0 0 8}$ &, $\mathbf{0 0 0}$ &, $\mathbf{0 0 0}$ \\
\hline
\end{tabular}

a Based on positive ranks.

b Based on negative ranks.

c Wilcoxon Signed Ranks Test.

Test Statistics(c): Hungary vs. other CEE Countries

\begin{tabular}{|l|r|r|r|r|}
\hline & $\begin{array}{c}\text { Poland - } \\
\text { Hungary }\end{array}$ & $\begin{array}{c}\text { Romania - } \\
\text { Hungary }\end{array}$ & $\begin{array}{c}\text { Slovakia - } \\
\text { Hungary }\end{array}$ & $\begin{array}{c}\text { Slovenia - } \\
\text { Hungary }\end{array}$ \\
\hline Z & $-3,774(\mathrm{a})$ & $-1,794(\mathrm{~b})$ & $-2,524(\mathrm{~b})$ & $-3,081(\mathrm{~b})$ \\
Asymp. Sig. (2-tailed) &, $\mathbf{0 0 0}$ &, 073 &, $\mathbf{0 1 2}$ & $\mathbf{0 0 2}$ \\
\hline
\end{tabular}

a Based on negative ranks.

b Based on positive ranks.

c Wilcoxon Signed Ranks Test.

Test Statistics(b): Poland vs. other CEE Countries

\begin{tabular}{|l|r|r|r|}
\hline & $\begin{array}{l}\text { Romania - } \\
\text { Poland }\end{array}$ & $\begin{array}{r}\text { Slovakia } \\
\text { - Poland }\end{array}$ & $\begin{array}{r}\text { Slovenia } \\
\text { - Poland }\end{array}$ \\
\hline Z & $-5,171(\mathrm{a})$ & $-5,228(\mathrm{a})$ & $-5,162(\mathrm{a})$ \\
$\begin{array}{l}\text { Asymp. Sig. (2- } \\
\text { tailed) }\end{array}$ & $\mathbf{, 0 0 0}$ & $\mathbf{, 0 0 0}$ &, $\mathbf{0 0 0}$ \\
\hline $\begin{array}{l}\text { a Based on positive ranks. } \\
\text { b Wilcoxon Signed Ranks Test. }\end{array}$ & \multicolumn{3}{|l}{} \\
\end{tabular}




\section{Appendix 2 (continued)}

Test Statistics(c): Romania vs. other CEE Countries

\begin{tabular}{l|r|r|}
\hline & $\begin{array}{c}\text { Slovakia - } \\
\text { Romania }\end{array}$ & $\begin{array}{c}\text { Slovenia - } \\
\text { Romania }\end{array}$ \\
\hline Z &,$- 117(\mathrm{a})$ &,$- 520(\mathrm{~b})$ \\
Asymp. Sig. (2-tailed) &, 907 &, 603 \\
\hline $\begin{array}{l}\text { a Based on negative ranks. } \\
\text { b Based on positive ranks. } \\
\text { c Wilcoxon Signed Ranks Test. }\end{array}$
\end{tabular}

Test Statistics(b): Slovakia vs. Slovenia

\begin{tabular}{|l|r|}
\hline & \multicolumn{1}{|c|}{$\begin{array}{c}\text { Slovenia - } \\
\text { Slovakia }\end{array}$} \\
\hline Z & $-1,227(\mathrm{a})$ \\
Asymp. Sig. (2-tailed) &, 220 \\
\hline
\end{tabular}

a Based on positive ranks.

b Wilcoxon Signed Ranks Test. 


\section{Appendix 3}

Wilcoxon Signed Rank Test on the Perception of Six Socio-Economic Key Drivers in the CEE Region

Descriptive Statistics

\begin{tabular}{|c|c|c|c|c|c|c|c|c|}
\hline & \multirow[t]{2}{*}{$\mathbf{N}$} & \multirow[t]{2}{*}{ Mean } & \multirow[t]{2}{*}{$\begin{array}{c}\text { Std. } \\
\text { Deviation }\end{array}$} & \multirow[t]{2}{*}{ Minimum } & \multirow[t]{2}{*}{ Maximum } & \multicolumn{3}{|c|}{ Percentiles } \\
\hline & & & & & & 25th & $\begin{array}{c}\text { 50th } \\
\text { (Median) }\end{array}$ & 75th \\
\hline $\begin{array}{l}\text { Economic } \\
\text { activity }\end{array}$ & 71 & 5,46 & 1,026 & 3 & 7 & 5,00 & 6,00 & 6,00 \\
\hline Capital market & 71 & 4,34 & 1,195 & 2 & 7 & 4,00 & 4,00 & 5,00 \\
\hline Taxation & 69 & 4,51 & 1,133 & 2 & 7 & 4,00 & 4,00 & 5,00 \\
\hline $\begin{array}{l}\text { Investor } \\
\text { protection }\end{array}$ & 70 & 4,21 & 1,318 & 1 & 7 & 3,00 & 4,00 & 5,00 \\
\hline $\begin{array}{l}\text { Social } \\
\text { environment }\end{array}$ & 67 & 4,33 & 1,006 & 2 & 6 & 4,00 & 4,00 & 5,00 \\
\hline $\begin{array}{l}\text { Entrepreneurial } \\
\text { opportunities }\end{array}$ & 69 & 5,03 & 1,236 & 3 & 7 & 4,00 & 5,00 & 6,00 \\
\hline
\end{tabular}

Test Statistics(b): Economic activity vs. other key drivers

\begin{tabular}{|l|r|r|r|r|r|}
\hline & $\begin{array}{c}\text { Capital } \\
\text { market - } \\
\text { Economic } \\
\text { activity }\end{array}$ & $\begin{array}{c}\text { Taxation - } \\
\text { Economic } \\
\text { activity }\end{array}$ & $\begin{array}{c}\text { Investor } \\
\text { protection - } \\
\text { Economic } \\
\text { activity }\end{array}$ & $\begin{array}{c}\text { Social } \\
\text { environment - } \\
\text { Economic } \\
\text { activity }\end{array}$ & $\begin{array}{c}\text { Entrepreneurial } \\
\text { opportunities - } \\
\text { Economic } \\
\text { activity }\end{array}$ \\
\hline Z & $-6,052(a)$ & $-5,631(\mathrm{a})$ & $-5,971(\mathrm{a})$ & $-6,092(\mathrm{a})$ & $-3,481(\mathrm{a})$ \\
Asymp. Sig. (2-tailed) & $\mathbf{, 0 0 0}$ & $\mathbf{, 0 0 0}$ & $\mathbf{, 0 0 0}$ & $\mathbf{0 0 0}$ & $\mathbf{0 0 0}$ \\
\hline
\end{tabular}

a Based on positive ranks.

b Wilcoxon Signed Ranks Test.

Test Statistics(c): Capital market vs. other key drivers

\begin{tabular}{|l|r|r|r|r|}
\hline & $\begin{array}{c}\text { Taxation - } \\
\text { Capital } \\
\text { market }\end{array}$ & $\begin{array}{c}\text { Investor } \\
\text { protection - } \\
\text { Capital } \\
\text { market }\end{array}$ & $\begin{array}{c}\text { Social } \\
\text { environment - } \\
\text { Capital market }\end{array}$ & $\begin{array}{r}\text { Entrepreneurial } \\
\text { opportunities - } \\
\text { Capital market }\end{array}$ \\
\hline Z & $-1,336(\mathrm{a})$ &,$- 894(\mathrm{~b})$ &,$- 204(\mathrm{~b})$ & $-4,737(\mathrm{a})$ \\
Asymp. Sig. (2-tailed) &, 182 &, 371 &, 838 &, 000 \\
\hline $\begin{array}{l}\text { a Based on negative ranks. } \\
\text { b Based on positive ranks. } \\
\text { c Wilcoxon Signed Ranks Test. }\end{array}$
\end{tabular}

Test Statistics(c): Taxation vs. other key drivers

\begin{tabular}{|c|c|c|c|}
\hline & $\begin{array}{l}\text { Investor } \\
\text { protection - } \\
\text { Taxation }\end{array}$ & $\begin{array}{l}\text { Social } \\
\text { environment - } \\
\text { Taxation }\end{array}$ & $\begin{array}{c}\text { Entrepreneurial } \\
\text { opportunities - } \\
\text { Taxation }\end{array}$ \\
\hline Z & $-2,098(a)$ & $-1,341(a)$ & $-3,026(b)$ \\
\hline Asymp. Sig. (2-tailed) & ,036 & , 180 & ,002 \\
\hline
\end{tabular}




\section{Appendix 3 (continued)}

Test Statistics(b): Investor Protection vs. Other Key Drivers

\begin{tabular}{|l|r|r|}
\hline & $\begin{array}{c}\text { Social } \\
\text { environment - } \\
\text { Investor } \\
\text { protection }\end{array}$ & $\begin{array}{c}\text { Entrepreneurial } \\
\text { opportunities - } \\
\text { Investor } \\
\text { protection }\end{array}$ \\
\hline Z &,$- 869(\mathrm{a})$ & $-4,245(\mathrm{a})$ \\
Asymp. Sig. (2-tailed) &, 385 &, $\mathbf{0 0 0}$ \\
\hline a Based on negative ranks. & & \\
b Wilcoxon Signed Ranks Test.
\end{tabular}

Test Statistics(b): Social Environment vs. Entrepreneurial opportunities

\begin{tabular}{|l|r|}
\hline & $\begin{array}{r}\text { Entrepreneurial } \\
\text { opportunities - } \\
\text { Social } \\
\text { environment }\end{array}$ \\
\hline Z & $-4,621(\mathrm{a})$ \\
Asymp. Sig. (2-tailed) &, 000 \\
\hline a Based on negative ranks. \\
b Wilcoxon Signed Ranks Test.
\end{tabular}

